\title{
Cross-Sectional Study of Improved Sanitary Facilities' Availability in an Urban Setting of Ghana
}

\author{
Anthony Mwinilanaa Tampah-Naah*, Anthony N-Yelkabong \\ Department of Environment and Resource Studies, Wa Campus, University for Development Studies, Tamale, \\ Ghana \\ Email: ${ }^{*}$ tonytampah@yahoo.com, anyelkabong@yahoo.com
}

Received 27 March 2015; accepted 12 April 2015; published 17 April 2015

Copyright (C) 2015 by authors and OALib.

This work is licensed under the Creative Commons Attribution International License (CC BY). http://creativecommons.org/licenses/by/4.0/

(c) (i) Open Access

\begin{abstract}
Background: The availability of sanitary facilities to human populations is deemed a necessity worldwide to promote healthy sanitation. In the Upper West Region, sanitation remains one of the major development challenges of our time, and despite growing attention and efforts by governments and donors, many approaches to urban and rural sanitation are failing. The study was conducted to examine environmental factors linked with sanitary facilities, and to assess socio-demographic factors with the availability, type and location of sanitary facilities in Mangu, a suburb of Wa Municipality, Ghana. Methods: A community-based cross-sectional quantitative study design was applied. The study population was made up of individuals of 18 years and abovein the community who had knowledge about the sanitary conditions within their respective housing units. From this population, 258 individuals were sampled for the study. Chi-square test for independence was applied to discover if there were associations between the study variables (sanitary facility accessibility and environmental characteristics of houses). Results: Factors associated with the availability of sanitary facilitiesin housing units were roofing material, building material, number of rooms, and drinking water source. Conclusions: The findings from the study indicate that a housing unit's conditions can significantly influence the availability of a sanitary facility in the community.
\end{abstract}

\section{Keywords}

Sanitary Facility, Housing Unit, Ghana

Subject Areas: Environmental Sciences

\footnotetext{
${ }^{*}$ Corresponding author.

How to cite this paper: Tampah-Naah, A.M. and N-yelkabong, A. (2015) Cross-Sectional Study of Improved Sanitary Facilities' Availability in an Urban Setting of Ghana. Open Access Library Journal, 2: e1217.
}

http://dx.doi.org/10.4236/oalib.1101217 


\section{Background}

The availability of sanitary facilities to human populations is deemed a necessity worldwide to promote healthy sanitation. The World Health Organization (WHO) establishes that a good sanitation can be attained when adequate facilities and services for the safe disposal of human urine and faeces, including garbage collection and wastewater disposal are made available [1]. The insufficient provision of sanitary facilities in households and communities poses poor sanitary conditions thereby increases the prevalence of diseases such as diarrhoea and cholera [1]. Poor sanitation, especially sanitary facilities, is a stern health risk affecting billions of people around the world. It has been projected that by 2015 there will be approximately 2.7 billion people without access to basic sanitation [2]. This kind of condition will definitely have an adverse impact on health status of people and undermine efforts to end sanitary related diseases in most poor and disadvantaged countries.

Generally, the sanitary facilities in sub-Saharan Africa need much attention. Sub-Saharan Africa is confronted with some of the worst deficits. In 2010, about 590 million lacked access to proper sanitation facilities [3]. People living in rural areas continue to be disproportionately underserved, with only $23 \%$ of the rural population of sub-Saharan Africa having access to proper basic sanitation in 2010 [3]. In 2011, 15\% of households used improved and not shared sanitation facilities and 23\% practiced open defecation or had no sanitary facilities [4] [5]. From the statistics over the years, the growth rate is far off-track in terms of achieving Millennium Development Goal 7 (MDG 7) Target 10 (to halve by 2015, the proportion of people without sustainable access to safe drinking water and basic sanitation). In Ethiopia, about $12 \%$ of the country's population has access to improved sanitation [JMP, 2010]. According to the World Bank's report on world development indicators the following countries' urban population have access to improved sanitation facilities: Togo (26\%), Nigeria (31\%), Cote d'Ivoire (33\%), Burkina Faso 50\%, Cameroon (62\%) and South Africa (82\%). On the part of sanitation, Ghana has only achieved $13 \%$ of its basic sanitation targets, which aim to increase the population's access to improved sanitation, as against the MDG target of 54\% [6].

It is estimated that less than $60 \%$ of solid waste generated in the country's capital, Accra, is collected, but its treatment and safe disposal remain the biggest challenge [7]. Also, it is estimated that $20 \%$ of households practise open defecation and 58\% use shared or public facilities which are unimproved (unhygienic) and $14 \%$ have access to improved toilets [8] in the country. The Coalition of Non-governmental Organizations in Water and Sanitation (CONIWAS) in the Upper West Region assert that limited prominence placed on community level sanitation, the lack of political will for providing adequate funds, low prestige and recognition associated with sanitation projects and ineffective policies are some factors that account for the deplorable sanitation situation in the region [9].

Similar studies have been conducted to ascertain related factors to the availability of sanitation facilities. Pore and Randive [10] conducted a study on environmental sanitation and personal hygiene in Maharashtra, India. Also, Yohannes et al. [11] conducted a study to assess the availability of improved sanitation facilities in terms of environmental, assistance and behavioural factors. In Ghana, Mahama [12] studied on the determinant-factors influencing households' access to improved water and sanitation facilities in Accra. The present study sought to contribute to the sanitation discourse by examining environmental factors and assessing socio-demographic factors with sanitary facilities.

In the Upper West Region, sanitation remains one of the major development challenges of our time, and despite growing attention and efforts by governments and donors, many approaches to urban and rural sanitation are failing [13]. Sanitary conditions prevailing in the region indicates that open defecation has reduced from 78.7\% to $71.1 \%$ in 2006 and 2011 respectively. Despite this reduction, the practice is still widespread with about 7 out of 10 household members practising open defecation [13]. Based on this, the study was undertaken to determine some environmental factors associated with the availability of sanitary facilities and to assess sociodemographic factors with the availability, type and location of sanitary facilities. In this regard, the paper takes another step in the quest to contribute to existing discourse on the access to sanitary facilities especially in developing countries.

\section{Methods}

\subsection{Study Design and Study Area}

A community-based cross-sectional quantitative study design was applied. The study was conducted in February, 
2014 in the Mangu Community of Wa Municipality, Ghana. The community has a total population of 3416 inhabitants (1814 males and 1647 females) [14].

The study area is located in the south-western part of the central business area of Wa Township; the regional capital of the Upper West Region. In relation to housing, there has been a rapid development of residential facilities due to the establishment of two main tertiary institutions; the University for Development Studies, Wa Campus and the Wa Polytechnic; to provide private hostel accommodation to students. The community also has a Community-based Health Practices and Services (CHPS) compound managed by Community Health nurses; where community members go for their health care needs especially mothers and children. Actually, in the community, there is no designated public toilet aside VIP latrines built for some basic schools; and some of the inhabitants have access to schools' VIP latrines.

\subsection{Study Population and Sampling Procedure}

The study population was made up of individuals of 18 years and above within the community who had knowledge about the sanitary conditions within their respective housing units. From this population, 258 individuals were sampled for the study.

In the present study, eligible respondents were sampled using cluster sampling approach. This sampling approach was applied since houses in the community were not numbered and not arranged in a uniform pattern. Two main visits were made to the study area. The study team initially visited the community to use identifiable landmarks to cluster the housing units. Based on the study area's map, the community was divided into two clusters using the main road that passed through the settlement; into eastern and western parts. From each of the two clusters, 129 houses were randomly sampled containing adults that had knowledge about the sanitary facilities and persons residing within their respective housing units. The second visit to the community was to collect the needed study data. With reference to the housing units clustered from the community, an adult (18 years and above), with informed consent, was randomly selected to respond to the study questionnaire.

\subsection{Data Collection and Statistical Analyses}

In the study, a 24-itemized-structured questionnaire was developed to collect the requisite data. The structured questionnaire consisted of three sections: socio-demographic characteristics of respondents, environmental characteristics of housing units, and access to sanitary facilities data.

Two data collectors were trained to assist in the data collection. This was done to ensure common ways of interviewing respondents, and to have consistent records of responses. The two researchers of the study acted as supervisors.

To ensure validity of the study's instrument, pretesting was carried out at Wa-Sombo; a community having similar characteristics as that of the study area. Inconsistencies in relation to question wordings and arrangements that emanated from the pretesting were clarified. During the data collection, the supervisors checked the administered questionnaires to ensure consistency and completeness.

The collected data were coded and entered into SPSS version 16 . The data were subsequently cleaned to facilitate analysis. Frequency tables were generated for all items on the study questionnaire. Chi-square test for independence was applied to discover if there were associations between the study variables (the dependent variable-sanitary facility accessibility—and independent variables-environmental characteristics of houses). Frequencies were run to assess various categories of the socio-demographic characteristics of respondents with sanitary facilities. The Pearson's statistic, with a $p$-value of 0.05 , was used to determine the statistical significance between the independent and dependent variables. This analysis procedure was deemed appropriate since the measure of the variables were either in ordinal or nominal levels and, also, the study variables consisted of two or more categorical mutually exclusive groups. Importantly, the chi-square was deemed applicable since none of the expected frequency of the variable categories was less than 5. Further, chi-square post hoc analysis was conducted to identify which cell or cells contributed to the significant chi-square test; thus between the independent variables and the dependent variable. Hence, using $p<0.05$, the study applied the standard residuals; thus $z$-score value of \pm 1.96 the equivalent of the $p$-value.

\subsection{Study Hypotheses}

The results of the chi-square test were used to draw conclusions on the following study hypotheses: 
$\mathrm{H}_{0}$ : There is no association between roofing material of a house and access to sanitary facility.

$\mathrm{H}_{0}$ : There is no association between building material of a house and access to sanitary facility.

$\mathrm{H}_{0}$ : There is no association between the number of house members and access to sanitary facility.

$\mathrm{H}_{0}$ : There is no association between the number of rooms in a house and access to sanitary facility.

$\mathrm{H}_{0}$ : There is no association between the source of drinking water and access to sanitary facility.

\subsection{Dependent Variable}

The study variables were selected after reviewing related literature in relation to the objectives of the study and by considering the local context of the study area. In the study, the dependent variable was sanitary facility availability. This was operationalized as a facility that hygienically separates human excreta from human contact including flush/pour flush toilets, ventilated improved pit (VIP) latrines and pit latrine with slap; that is at hand when needed. For the purpose of analysis, sanitary facility availability was captured as either having a sanitary facility or not having a sanitary facility. Hence, a question was asked as "Do you have a sanitary facility in your house?" and the response to this question was either "yes" or "no".

Further, related questions were posed to those who answered in the affirmative to having access to a sanitary facility in their various housing units. These questions include when the sanitary facility was built, whether sanitary facility was shared with different house members, the type of sanitary facility, who constructed the sanitary facility, whether the sanitary facility was functional, and where the sanitary facility was located.

\subsection{Independent Variables}

The independent variables included socio-demographic variables (age, sex, marital status, education, occupation, and religion), and environmental variables (house's main roofing material, house's main building material, number of house members, number of rooms, and main source of drinking water).

\subsection{Ethical Considerations}

The study was carried out in compliance with the Helsinki Declaration on conducting research on humans. In addition, informed oral consent was obtained from respondents before data were collected. Respondents were also made aware that they were not obliged to answer all questions, and that they could withdraw from the study at any point of the data collection. Respondents were also assured of confidentiality with their identity and the data they provided.

\section{Results}

In the study, a total of 258 respondents, each representing a house unit, were interviewed. Based on the core issue of the study, majority (66\%) of the houses did not have a sanitary facility. Out of those which had a sanitary facility, most of the facilities were about two years old, majority (53\%) of the facilities were not shared with other housing units. Most (45\%) of these sanitary facilities were VIP (Ventilated Improved Pits) toilets, and majority (79\%) the house owners financed the construction of sanitary facilities. Besides, majority (93\%) of the sanitary facilities were functional, and most (57\%) of them were located within the housing units (Table 1).

The study revealed that $71 \%$ of the respondents were in the 18 - 39 years age category and most (57\%) of them were married. Among the respondents, about four in ten (42\%) were of the Dagaaba ethnic group and majority (53\%) of them were males. In terms of religion, most (48\%) of them were Moslems and about 35\% did not have any formal education. Likewise, $48 \%$ were farmers or traders (Table 2).

In the community, $32 \%$ of respondents (18 - 39 years old) had access to improved sanitary facility, mainly made up of VIP toilets and most were located within their respective compounds. With marital status and improved sanitary facilities, 35\% married respondents had access to improved sanitary facilities and $40 \%$ of the facilities were VIP toilets and located within their individual compounds. In terms of ethnicity, $76 \%$ respondents of the Waala ethnic group did not have access to an improved sanitary facility, 67\% of Sissalas used VIP toilets, and most of the Mole-Dagbanis' facilities were located within their compounds. With sex, almost an equal number of males and females did not have access to improved facilities, more females (52\%) use VIP toilets. Also, most (76\%) of those of the Islamic religion did not have access to improved facilities, $64 \%$ of the Traditionalists have access to VIP toilets, and $65 \%$ of Christians facilities were located within their compounds. On 
Table 1. Sanitation facilities availability.

\begin{tabular}{|c|c|c|}
\hline Characteristic & $\mathbf{n}$ & $\%$ \\
\hline \multicolumn{3}{|l|}{ Sanitary facility $(n=258)$} \\
\hline Yes & 89 & 34.5 \\
\hline No & 169 & 65.5 \\
\hline \multicolumn{3}{|c|}{ Sanitary facility existence (89) } \\
\hline One year & 7 & 7.9 \\
\hline Two years & 31 & 34.8 \\
\hline Three years & 19 & 21.3 \\
\hline Four years & 15 & 16.9 \\
\hline Five years & 10 & 11.2 \\
\hline More than five years & 7 & 7.9 \\
\hline \multicolumn{3}{|c|}{ Share sanitary facility $(n=89)$} \\
\hline Yes & 42 & 47.2 \\
\hline No & 47 & 52.8 \\
\hline \multicolumn{3}{|c|}{ Sanitary facility type $(n=89)$} \\
\hline Flush/pour flush & 31 & 34.8 \\
\hline VIP toilet & 40 & 44.9 \\
\hline Pit latrine with slap & 18 & 20.3 \\
\hline \multicolumn{3}{|c|}{ Sanitary facility construction $(n=89)$} \\
\hline Self & 70 & 78.7 \\
\hline NGO & 10 & 11.2 \\
\hline Assembly & 9 & 10.1 \\
\hline \multicolumn{3}{|c|}{ Sanitary facility functional $(n=89)$} \\
\hline Yes & 83 & 93.3 \\
\hline No & 6 & 6.7 \\
\hline \multicolumn{3}{|c|}{ Sanitary facility location $(n=89)$} \\
\hline Within compound & 51 & 57.3 \\
\hline Out of compound & 38 & 42.7 \\
\hline
\end{tabular}

education, $80 \%$ of those without education did not have access to an improved facility, $67 \%$ of them use VIP toilets, and $79 \%$ of those of the tertiary level had their facilities located within their compounds. Most (70\%) unemployed respondents did not have access to improved facilities, $55 \%$ of farmers or traders use VIP toilets, and $58 \%$ of those who were unemployed had their facilities located within their compounds.

Also, on the environmental characteristics of the houses, the study revealed that $93 \%$ of the houses were roofed with zinc or aluminum sheets and $74 \%$ were built with concrete blocks. In relation to occupancy, 38\% houses had about 6 - 10 members and 42\%houses had 1 - 5 rooms. In the community, the main source of drinking water was borehole water; indicated by $62 \%$ of the respondents (Table 3 ).

A chi-square test of independence was performed between sanitary facilities availability and the environmental variables (main roofing material, main building material, number of house-unit members, number of rooms, and main drinking water source). All these variables exhibited statistically significant $(p<0.05)$ association with sanitary facility availability except number of house-unit members (Table 3). Post hoc analysis was therefore conducted on main roofing material, main building material, number of rooms, and main drinking water source to examine which of their cell or cells contributed to the statistically significant difference (z-score value of 
Table 2. Socio-demographic characteristics and access to sanitation facilities ( $\mathrm{N}=258)$.

\begin{tabular}{|c|c|c|c|c|c|c|c|c|c|}
\hline \multirow{3}{*}{$\begin{array}{l}\text { Socio-demographic } \\
\text { characteristic }\end{array}$} & \multirow{2}{*}{\multicolumn{2}{|c|}{$N=258$}} & \multicolumn{7}{|c|}{ Improved sanitation facility $(\mathrm{n}=\mathbf{8 9})$} \\
\hline & & & \multicolumn{2}{|c|}{ Available } & \multicolumn{3}{|c|}{ Type } & \multicolumn{2}{|c|}{ Location } \\
\hline & $\mathbf{n}$ & $\%$ & Yes & No & $\begin{array}{c}\text { Flush/ } \\
\text { pour flush }\end{array}$ & VIP toilet & $\begin{array}{l}\text { Pit latrine } \\
\text { with slap }\end{array}$ & $\begin{array}{l}\text { Within } \\
\text { compound }\end{array}$ & $\begin{array}{c}\text { Outside } \\
\text { compound }\end{array}$ \\
\hline
\end{tabular}

\section{Age (years)}

$\begin{array}{llllllllll}18-39 & 185 & 71.7 & 32.4 & 67.6 & 35.0 & 46.7 & 18.3 & 56.7 & 43.3 \\ 40 \text { and above } & 73 & 28.3 & 39.7 & 60.3 & 34.5 & 41.4 & 24.1 & 58.6 & 41.4\end{array}$

\section{Marital status}

$\begin{array}{llllllllll}\text { Married } & 148 & 57.4 & 35.0 & 46.7 & 38.1 & 40.5 & 21.4 & 61.9 & 38.1 \\ \text { Not married } & 110 & 42.6 & 34.5 & 41.4 & 31.9 & 48.9 & 19.1 & 53.2 & 46.8\end{array}$

\section{Ethnicity}

\begin{tabular}{|c|c|c|c|c|c|c|c|c|c|}
\hline Dagaaba & 107 & 41.5 & 34.6 & 65.4 & 45.9 & 40.5 & 13.5 & 67.6 & 32.4 \\
\hline Waala & 94 & 36.4 & 24.5 & 75.5 & 17.4 & 65.2 & 17.4 & 34.8 & 65.2 \\
\hline Sissala & 19 & 7.4 & 47.4 & 52.6 & 11.1 & 66.7 & 22.2 & 44.4 & 55.6 \\
\hline Mole-Dagbani & 25 & 9.7 & 40.0 & 60.0 & 50.0 & 20.0 & 30.0 & 80.0 & 20.0 \\
\hline Akan/Ewe/Ga & 13 & 5.0 & 76.9 & 23.1 & 40.0 & 20.0 & 40.0 & 60.0 & 40.0 \\
\hline
\end{tabular}

Sex

$\begin{array}{llllllllll}\text { Male } & 137 & 53.1 & 34.3 & 65.7 & 36.2 & 38.3 & 25.5 & 55.3 & 44.7 \\ \text { Female } & 121 & 46.9 & 34.7 & 65.3 & 33.3 & 52.4 & 14.3 & 59.5 & 40.5\end{array}$

\section{Religion}

$\begin{array}{lccccccccc}\text { Christianity } & 111 & 43.0 & 41.4 & 58.6 & 47.8 & 34.8 & 17.4 & 65.2 & 34.8 \\ \text { Islamic } & 123 & 47.7 & 23.6 & 76.4 & 27.6 & 51.7 & 20.7 & 55.2 & 44.8 \\ \text { Traditional } & 24 & 9.3 & 58.3 & 41.7 & 7.1 & 64.3 & 28.6 & 35.7 & 64.3\end{array}$

\section{Education}

\begin{tabular}{|c|c|c|c|c|c|c|c|c|c|}
\hline No education & 89 & 34.5 & 20.2 & 79.8 & 16.7 & 66.7 & 16.7 & 33.3 & 66.7 \\
\hline Primary & 30 & 11.6 & 23.3 & 76.7 & 0 & 100 & 0 & 42.9 & 57.1 \\
\hline Junior High School & 39 & 15.1 & 35.9 & 64.1 & 21.4 & 50.0 & 28.6 & 50.0 & 50.0 \\
\hline Senior High School & 31 & 12.0 & 38.7 & 61.3 & 25.0 & 41.7 & 33.3 & 41.7 & 58.3 \\
\hline Tertiary & 69 & 26.7 & 55.1 & 44.9 & 57.9 & 23.7 & 18.4 & 78.9 & 21.1 \\
\hline \multicolumn{10}{|l|}{ upation } \\
\hline Unemployed & 87 & 33.7 & 29.9 & 70.1 & 46.2 & 38.5 & 15.4 & 57.7 & 42.3 \\
\hline Farmer/Trader & 124 & 48.1 & 33.9 & 66.1 & 23.8 & 54.8 & 21.4 & 47.6 & 52.4 \\
\hline Civil/public servant & 28 & 10.9 & 50.0 & 50.0 & 42.9 & 35.7 & 21.4 & 71.4 & 28.6 \\
\hline Student & 19 & 7.4 & 36.8 & 63.2 & 42.9 & 28.6 & 28.6 & 57.3 & 14.3 \\
\hline
\end{tabular}

Figures under available, type and location are presented in percentages; $\mathrm{n}$-frequency; \%—percentage; $\mathrm{N}$-sample size. 
Table 3. Association between sanitation availability and environmental characteristics $(n=258)$.

\begin{tabular}{|c|c|c|c|c|c|c|c|}
\hline \multirow{3}{*}{ Environmental characteristic } & \multirow{3}{*}{$\mathbf{n}$} & \multirow{3}{*}{$\%$} & \multicolumn{2}{|c|}{ Sanitation facility } & \multirow{3}{*}{$\chi^{2}$ (p-value) } & \multirow{2}{*}{\multicolumn{2}{|c|}{$\begin{array}{c}\text { Std. residuals } \\
\text { Sanitation facility }\end{array}$}} \\
\hline & & & \multirow{2}{*}{ Yes n (\%) } & \multirow{2}{*}{ No n (\%) } & & & \\
\hline & & & & & & Yes & No \\
\hline Main roof material & & & & & $9.41(0.009)^{* *}$ & & \\
\hline Thatch/Mud & 18 & 7.0 & $12(66.7)$ & $6(33.3)$ & & $2.3^{*}$ & -1.7 \\
\hline Zinc/Aluminum sheets & 240 & 93.0 & $77(32.1)$ & 163 (67.9) & & -0.6 & 0.5 \\
\hline Main building material & & & & & $12.48(0.000)^{* *}$ & & \\
\hline Mud & 66 & 25.6 & $11(16.7)$ & $55(83.3)$ & & $-2.5^{*}$ & 1.8 \\
\hline Concrete blocks & 192 & 74.4 & 78 (40.6) & $114(59.4)$ & & 1.4 & -1.0 \\
\hline House-unit members & & & & & $5.78(0.216)$ & & \\
\hline $1-5$ & 81 & 31.4 & $23(28.4)$ & $58(71.6)$ & & & \\
\hline $6-10$ & 98 & 38.0 & $32(32.7)$ & $66(67.3)$ & & & \\
\hline $11-15$ & 47 & 18.2 & $18(38.3)$ & $29(61.7)$ & & & \\
\hline$>16$ & 32 & 12.4 & $16(5.0)$ & $16(50.0)$ & & & \\
\hline Number of rooms & & & & & $12.04(0.017)^{* *}$ & & \\
\hline $1-5$ & 107 & 41.5 & $29(27.1)$ & 78 (72.9) & & -1.3 & 0.9 \\
\hline $6-10$ & 103 & 39.9 & $35(34.0)$ & $68(66.0)$ & & 0.0 & 0.1 \\
\hline $11-15$ & 30 & 11.6 & $13(43.3)$ & $17(56.7)$ & & 0.8 & -0.6 \\
\hline$>16$ & 18 & 7.0 & $12(66.7)$ & $6(33.3)$ & & $2.3^{*}$ & -1.7 \\
\hline Main drinking water source & & & & & $8.635(0.013)^{* *}$ & & \\
\hline Pipe & 63 & 24.4 & $16(25.4)$ & $47(74.6)$ & & -1.2 & 0.9 \\
\hline Borehole & 158 & 61.2 & $53(33.5)$ & $105(66.5)$ & & -0.2 & 0.1 \\
\hline Dug well & 37 & 14.3 & $20(54.1)$ & 17 (45.9) & & $2.0 *$ & -1.5 \\
\hline
\end{tabular}

$\boldsymbol{X}^{2}$ — chi-square; p-value — probability value; **_Statistically significant level $(p<0.05)$; — cells that contributed much to the chi-square test; Std. Residuals-Standard Residuals (converted to z-score [+/- 1.96] equivalent to an alpha of 0.05 ).

$\pm 1.96)$ between the independent variables and the dependent variable.

The chi-square test indicates that there was significant association between main roofing material and the presence of a sanitary facility, $\chi^{2}(2)=9.41, p<0.009$. Based on this result, the hypothesis that there is no association between roofing main material of a house and the availability to sanitary facility was rejected. It indicates that the availability of a sanitary facility is dependent on the kind of roofing material used for a house. With the post hoc test (z-score $=2.3$ ), only those who used thatch or mud to roof their houses and had a sanitary facility contributed much to the chi-square association between main roofing material and the availability of sanitary facility.

Likewise, the chi-square test shows that there was a significant association between main building material and the availability of a sanitary facility, $\chi^{2}(1)=12.48, p<0.000$. Since there was an association between main building material of a house and availability to sanitary facility, the null hypothesis was rejected. That is, the kind of material that is used to build a house can determine the existence of a sanitary facility. Further post hoc analysis (z-score $=-2.5$ ) indicated that house-units that were built with mud and had a sanitary facility, contributed much to the chi-square association between the main building material and sanitary facility.

In relation to the number of house-unit members, no significant association was established; $\chi^{2}(4)=5.78, p<$ 0.216. Based on this result, the study failed to reject the null hypothesis. The study therefore concluded that 
there is no association between number of members in a house and access to sanitary facility. It implies that the availability of a sanitary facility is not dependent on the number of a house-unit's members.

Similarly, it was found that there was a significant association between number of rooms and the availability of a sanitary facility; $\chi^{2}(4)=12.04, p<0.017$. Since the $p$-value was less than 0.05 , the null hypothesis, thus there is no association between number of rooms and availability to sanitary facility, was also rejected. This finding reveals that the number rooms can influence the presence of a sanitary facility. The results of the post hoc test (z-score $=2.3$ ) revealed that house-units that had 16 or more rooms and had a sanitary facility contributed much to the chi-square association between the number of rooms and sanitary facility.

The test on the main source of drinking water showed a significant association with the availability of sanitary facility; $\chi^{2}(2)=8.635, p<0.013$. With this result, the null hypothesis that there is no association between source of drinking water of house occupants and access to sanitary facility was rejected. It means that, the source of drinking water can impact on the availability of a sanitary facility. Also, the post hoc test $(z-s c o r e=2.0)$ showed that house-units that use dug well water as their main drinking source and had a sanitary facility contributed much to the chi-square association identified between drinking water source and sanitary facility.

\section{Discussion}

The prevalence of improved sanitary facilities among housing units in the study area was 35\%. It should be noted that, in the study area, and Ghana as a whole, most housing units consist of a number of households in both urban and rural areas. With this kind of living arrangement, it implies that many housing units do not have their own sanitary facility, and hence, most of them use shared facility or practice open defecation. The incidence of open defecation is an environmental and health problem facing Ghana [15]. It is estimated that sixteen million people in Ghana use shared sanitary facilities and about 5.7 million have no latrines at all and, hence, practice open defecation [16]. This undoubtedly has led to the outbreak of diseases such as cholera. This costs the country a whopping amount of 79 million dollars per annum [17].

In the study, improved sanitary facility was operationalized as a facility that hygienically separates human excreta from human contact including flush/pour flush toilets, ventilated improved pit (VIP) latrines, and pit latrine with slap [18]. The discussion is focused on how percentages of socio-demographic characteristics are linked with improved sanitary facilities and the environmental factors associated with improved sanitary facilities using chi-square test.

The study revealed that many people in the community did not have access to improved sanitary facilities; this was reflective across all categories of respondents. This finding resonates with a study conducted by Mahama [12] in Accra, capital city of Ghana, indicated that $34.7 \%$ of respondents had access to improved sanitary facilities. The present study's result is also similar to a study conducted by Yohannes et al. [11] in Ethiopia. Most of the respondents indicated that they have access to VIP toilet. Although the VIP toilets are limited in the community, they offer an opportunity to those who would like to use an improved sanitary facility. This kind of improved sanitary facility is common in the country and it is commonly called "public toilet". Most of these "public toilets" have deplorable conditions due to poor building materials used or insufficient management practices. This, undoubtedly, compel residents to practice open defecation since just a few have their own personal toilets - flush or pour flush toilets [19]. The few respondents that have access to improved sanitary facilities indicated that these facilities were located within their compounds. This result may be associated with residents not have the sufficient money or placing much importance on constructing improved sanitary facilities within their compounds.

The appearance of a house can indicate the kind of facilities it is likely to have. The study shows that the main material that was used to roof a house was associated with the accessibility of a sanitary facility. Most houses that had a sanitary facility used zinc or aluminum sheets as their main roofing material while a few houses that had thatch as their main roofing material had sanitary facilities. This finding can also be interpreted that those who use zinc or aluminum sheets to roof their houses are of a better economic standing and can afford to construct sanitary facilities within their houses compared to those who used thatch to roof their houses. In a similar finding, the main material used to construct a house was found to be statistically associated with the accessibility of a sanitary facility in a house. Most houses that had a sanitary facility were built using concrete blocks. The rest of the houses that built using mud had fewer sanitary facilities. This further goes to affirm that an individual's wealth quintile tends to significantly indicate the provision of basic facilities like a sanitary facility in a 
house that they may construct. In other words, houses that are constructed with more durable building materials have better and more installed basic facilities including a sanitary facility compared to houses built with less durable materials. The underlying factor contributing to the lack of improved sanitary facilities in most the houses is the cost of construction. The present study's finding is similar to a study conducted in Nigeria on sanitation facilities and hygiene practices [20]. This study established that cost of constructing a sanitary facility was hindering most residents from owning personal toilets.

Likewise, another housing feature that was found to be associated with sanitary facility accessibility was the number of rooms in a house. Most of these houses had their sanitary facility located within their houses and most of them were functional. This may be attributed to the fact that most of the housing-units in the community are built to accommodate mostly working populations or students. This category of people most likely rent apartments that have at least basic improved facilities. So, the more tenants a house can accommodate the likelihood that it may have an improved sanitary facility.

Sanitation and water are closely related and the presence of both in a particular environment can promote health [21]. In this present study, the main source of drinking water was also associated with the accessibility of a sanitary facility in a house. Most houses that have improved sanitary facilities indicated that they mainly use borehole water. This finding can be attributed to the usage of one borehole by a number of individuals from different housing units in the community.

\section{Limitations}

This study was not devoid of limitations. There might have been a recall bias on the responses given by the study respondents. Also, the sample size of the study was small and enough analysis could not be performed further on the study variables to determine socio-demographic factors that predicted the availability of improved sanitary facilities in the community. Hence, inferential interconnections could not be drawn between these independent variables and the availability of improved sanitary facilities. Despite these identified limitations, the findings represent the general picture of the availability of sanitary facilities in the community.

\section{Conclusion}

The findings from the study indicate that the characteristics of a house significantly influence the availability of a sanitary facility in the community. Hence, this reflects the general condition of the availability of sanitary facilities in the country. It is recommended that local authorities, such as the Municipal Assemblies and Environmental Health Offices, should place much attention on houses with less durable building materials, such as mud and thatch, in the provision of sanitary facilities.

\section{Competing Interests}

The authors declare that they have no competing interests.

\section{Authors' Contributions}

AMTN drafted the proposal, designed the study and conducted the data analysis. AN contributed to the study's questionnaire development and pretesting. AMTN and AN supervised the data collectors and data entry. Both authors have read and approved the final manuscript.

\section{Acknowledgements}

We are thankful to study respondents for their cooperation and the Municipal Environmental Health Office for the information provided during the study's proposal development. We also are grateful to the data collectors.

\section{References}

[1] World Health Organization (WHO) (2013) Health Topics: Sanitation. http://www.who.int/topics/sanitation/en/

[2] World Health Organization (WHO) (2011) Ten Facts on Sanitation. http://www.who.int/features/factfiles/sanitation/en/index.html

[3] ONE (2013) Water and Sanitation: The Challenges. http://www.one.org/c/international/issue/954/ 
[4] Ghana Statistical Service (GSS) (2007) Multiple Cluster Indicator Survey 2006. GSS, Accra.

[5] Ghana Statistical Service (GSS) (2012) Multiple Cluster Indicator Survey 2011. GSS, Accra.

[6] Water and Sanitation Sector Monitoring Platform (2008) Use of Improved Sanitation Facilities in Ghana. Ministry of Water Resources, Works and Housing, Accra.

[7] Anomanyo, E.D. (2004) Integration of Municipal Solid Waste Management in Accra (Ghana): Bioreactor Treatment Technology as an Integral part of the Management Process. Habitat International, 39, 96-104.

[8] World Health Organization (WHO), United Nations Children Fund (UNICEF) (2012) Progress on Drinking Water and Sanitation-2012 Update. WHO/UNICEF, Geneva/New York.

[9] Coalition of Non-Governmental Organizations in Water and Sanitation (CNIWAS) (2008) Sanitation Still Poor. http://wa.ghanadistricts.gov.gh/?arrow=nws\&read=18855

[10] Pore, S.M. and Randive, S.D. (2014) A Study on Environmental Sanitation, and Personal Hygiene among the Slum Area in Solapur City, Maharashtra, India. Advances in Applied Science Research, 5, 98-101.

[11] Yohannes, T., Workicho, A. and Asefa, H. (2014) A Cross Sectional Study: Availability of Improved Sanitation Facilities and Associated Factors among Rural Communities in Lemo Woreda, Hadiya Zone, Southern Ethiopia. OALib, 1, 1-10. http://dx.doi.org/10.4236/oalib.1101020

[12] Mahama, A.M. (2013) Determinants of Factors Influencing Householders’ Access to Improved Water and Sanitation Facilities in Selected Low-Income Urban Areas of Accra. Unpublished Master's Thesis, Institute of Statistical, Social and Economic Research, University of Ghana, Legon.

[13] Environmental Health Department (2014) Sanitation: EHD 2013 Annual Report. EHD, Wa Municipality.

[14] Ghana Statistical Service (2012) 2010 Population and Housing Census. GSS, Accra.

[15] Acheampong, E. (2010) Open Defecation in Accra; Health and Environmental Implications. http://www.modernghana.com/news/298998/1/open-defecation-in-accra-health-and-environmental-.html

[16] Smith-Asante, E. (2013) Daily Open Defecation Hits over 5.7 Million in Ghana. http://www.spyghana.com/daily-open-defecation-hits-over-5-7-million-in-ghana/

[17] Global Voices (2014) Searching for Solutions to Open Defecation in Ghana. https://globalvoicesonline.org/2014/02/03/searching-for-solutions-to-open-defecation-in-ghana/

[18] Water and Sanitation Sector Monitoring Platform, WSMP (2008) Status of Ghana’s Drinking Water and Sanitation Sector. www.wsmp.org/downloads/country-summary-sheet-09.pdf

[19] Spencer, M.C. (2012) Sanitation Practices and Preferences in Peri-Urban Accra, Ghana. Hubert Department of Global Health, Emory University, Atlanta.

[20] Ordinioha, B. and Owhondah, G. (2008) Sanitation Facilities and Hygiene Practices in a Semi-Urban Community in Rivers State, South-South Nigeria. The Nigerian Health Journal, 8, 10-15.

[21] Cheng, J.J., Schuster-Wallace, C.J., Watt, S., Newbold, B. and Mente, A. (2012) A Ecological Quantification of the Relationships between Water, Sanitation and Infant, Child, and Maternal Mortality. Environmental Health, 11, 4. http://dx.doi.org/10.1186/1476-069X-11-4 